\section{Influence of demographic factors on knowledge sharing among researchers in selected research institutes in Ibadan, Nigeria}

Folashade Munirat Lawal

Afe Babalola University, Ado-Ekiti, Nigeria

Chuks Daniel Oriogu

Afe Babalola University, Ado-Ekiti, Nigeria

\author{
Sussan Udoaku Ogbuiyi \\ Babcock University, Illisan-Remeo, Nigeria
}

Information Impact:

Journal of Information and Knowledge Management 2017, Vol. 8 (2) Pg 63 - 76 ISSN: $2141-4297$ (print) ISSN: 2360 - 994X (e-version) www.informationimpact.org

\begin{abstract}
Knowledge sharing is an effective means to provide information for organizational growth. The study investigated the influence of demographic factors on knowledge sharing among researchers in selected research institutes in Oyo state, Nigeria. The study adopted survey research method. Total enumeration technique was used to cover all the 440 researchers in the four selected research institutes in Ibadan, Oyo State in Nigeria. Five (5) research questions guided the study and three hypotheses were tested at 0.05 level of significance. Data were analysed using descriptive statistics. The findings of the study reveals that, there were significant relationship between knowledge sharing and gender $(r=0.1 ; p<0.5)$ and rank of researcher $(\mathrm{r}=0.1 ; \mathrm{p}<0.5)$. Knowledge sharing correlated with each of researcher demographic factors: age, gender, marital status, religion, and educational level. The study recommends that necessary encouragement by institutions should be given to the researchers to improve their knowledge sharing behavior. In addition, adequate training and re-training should be provided as well as stable Internet connectivity.
\end{abstract}

Keywords: knowledge sharing, demographic factors, research institutes, researchers

\title{
Introduction
}

The role of research institutes cannot be underestimated in the development of a nation. Research institutes are established and empowered to undertake various developmental researches in all sphere of human endeavor. For any nation to function effectively, knowledge is the bedrock for growth. It is the pivotal engine that aids effective growth in an organization. It is today one of the key drivers of modern organizations and has the same importance as effectiveness and competitiveness (Wiig, 2004). 
Knowledge has been identified as the most strategically significant resource for organizations to gain competitive advantage and superior performance (Spender, 1996; Grant, 1996, Gold, Malhotra \& Segars, 2001). Knowledge is an essential commodity that promotes organizational effectiveness and growth. According to Grubić-Nešić, Matić and Mitrović (2014) knowledge can be defined as a combination of experience, contextual information that provides a framework for the evaluation and application of new information and newly acquired experiences. One of the key factor of knowledge management is knowledge sharing. It helps to facilitate the access and use of knowledge in any organizations. It is a means by which, organizational member can contribute to knowledge application, innovation, and ultimately the competitive advantage of the organization (Jackson, 2006). Knowledge sharing is becoming increasingly a vital source of growth in any organization whose goal is to achieve high production and contribute meaningfully to the national development. This is why the study investigates the influence of demographic factors on knowledge sharing among researchers in selected research institutes in Ibadan, Nigeria.

\section{Literature review}

Knowledge sharing refers to the willingness of individuals in an organization to share whatever they have or create (Gibbert \& Krause, 2002). Knowledge sharing is the provision of task information and know-how to help others and to collaborate with others to solve problems, develop new ideas, or implement policies or procedures (Cummings, 2004; Pulakos, Dorsey, \& Borman, 2003). It is the process by which a person or an organization collaborate together to share information that will be beneficial to them. Some organizations attain competitive advantages by encouraging and promoting knowledge sharing (Liebowitz, 2001). Thus, knowledge sharing is important to organisational success. The essence of knowledge sharing is even more desired in knowledge-intensive organisations (like universities and research institutes). Such institutions need to share knowledge held by employees if they want to benefit from their intellectual capital and compete effectively in the global marketplace (Swart \& Kinnie, 2003). In the same vein, Steyn (2004) advanced that, to harness the power of knowledge in higher education; management should give an equal emphasis on people, technology, and structures. Hence, there is a need for the careful transmission and absorption by the sender and potential receiver respectively for such knowledge sharing to be effective (Hawamdeh, 2003). Therein, for effective knowledge sharing process, there need to understand the role of demographic factors in knowledge sharing.

Demographic factors are studies of a population based on factors such as age, race, sex, economic, status, level of education, income level. They are personal characteristics used to collect and evaluate data on people in a given population. Gender differences have been an issue in the forefront of public discussion in all spheres of life. In the educational parlance, gender difference has been recorded in terms of skills acquisition, information literacy, classroom 
interaction, reading habits, professional development. Mogotsi, and Fletcher (2011) investigated the relationships between knowledge sharing behaviour and the demographic variables such as gender, age, organizational tenure and professional tenure. The study revealed that there is no statistically significant relationship between knowledge sharing behaviour and gender, age, or professional tenure. Only organisational tenure observed to be weakly negatively correlated with knowledge sharing behaviour. According to Shi-Jer Lou et al., (2007) socio demographic factors such as the age, educational background, seniority in teaching, job title, marital status, number of children and location have showed significant difference regarding the knowledge sharing behaviour of management instructors of Technological Universities at Southern Taiwan. The aspects of knowledge sharing between instructors were correlated with their demographic information

The characteristics of individual influence their willingness to share knowledge. Subjective norms were incorporated in many models as a factor that influences knowledge sharing. Bock et al (2005) and Lee and Hong (2014) found strong association between the subjective norm of individuals and their willingness to share knowledge. Further, researchers focused on the ability of individual to share the knowledge. Self-efficacy was found by many researchers to influence employees' willingness to share knowledge (Lin, 2007, Van Acker et al, 2014 \& Chou et al, 2014).

An organization seeking to establish knowledge sharing culture must ensure that the top management supports the initiatives and pays efforts and attentions for the practices of knowledge sharing. Management must support and enforce the positive behaviour of knowledge sharing (Lin, 2007, Mueller, 2012, Kathiravelu et al 2014). Furthemore, trust has emerged as an important factor inside and outside the organization for knowledge sharing (Mohamed, Ann \& Yee, 2014). The importance of trust is supported by many other studies (Connelly \& Kelloway, 2000; Ardichvili et al., 2003; Politis, 2003). In Connelly and Kelloway's (2000) study, respondents said that they would only be willing to share knowledge in contexts where they trusted the recipients of the knowledge. Ardichvili et al (2003) pointed out the importance of both knowledge-based trust and institution-based trust in knowledge sharing. In terms of care or empathy, Von Krogh (1998) proposed a framework to show how empathy among organization members promotes effective knowledge sharing. The organization should create a culture of sharing that facilitates knowledge sharing and the structure of the company must be in shape that can speed the knowledge sharing (Kathiravelu et al 2014). Knowledge sharing is becoming increasingly important to ensure that practice and policy are based on sound evidence. For this to happen, the gaps among research, practice, and policy must be bridged. Knowledge sharing is a tool that can be used to promote evidence-based practice and decision making, and also to promote exchange and dialogue among researchers, policymakers, and service providers. However, little is known about knowledge-sharing strategies and their effectiveness and the interplay of demographic factors in Nigeria. This is why the study investigates the influence of 
demographic factors on knowledge sharing among researchers in selected research institutes in Ibadan, Nigeria. This study investigated the influence of demographic factors on knowledge sharing among researchers in four research institutes. The study covers some research institutes in Ibadan, Oyo State which include Institute of Agricultural Research and Training (IAR\&T), Forestry Research Institute of Nigeria (FRIN), Cocoa Research Institutes in Nigeria (CRIN) and National Horticultural Research Institute (NIHORT). It focuses specifically on the researchers in the selected research institutes.

\section{Objectives of the study}

The main objective of the study is to investigate the influence of demographic factors on knowledge sharing among researchers in four research institutes in Ibadan. The specific objectives are to:

I. Examine the methods of knowledge sharing among researchers in the selected Research Institutes in Ibadan.

II. Determine the effects of demographic factors on knowledge sharing among researchers in the selected research Institutes in Ibadan.

III. Identify the challenges to knowledge sharing among researchers in the selected Research Institutes in Oyo State.

\section{Hypotheses}

The following hypotheses will be tested at 0.05 level of significance:

Ho1: There will be no significant difference in the gender of researchers and knowledge sharing in the selected research Institutes.

Ho2: There will be no significant difference in the rank of researchers and knowledge sharing in selected research Institutes.

Ho3: There will be no significant difference between demographic factors and knowledge sharing among researchers in the selected research Institutes.

\section{Methodology}

Survey research method was adopted for the study and structured questionnaire was used to collect data. Five (5) research questions guided the study and three hypotheses were tested at 0.05 level of significance. The total numbers of the questionnaire administered to the respondents was four hundred and fourth (440) while only four hundred and one (401) were correctly filled and returned. Data were analysed using descriptive statistics, multiple regression, pearson product moment correlation and content analysis. Thus, Total enumeration technique was used to cover all the researchers in the four selected research institutes in Ibadan, Oyo state in Nigeria. 
Findings and discussion

Table 1: Distribution of respondents by research institutes.

\begin{tabular}{|l|l|l|r|}
\hline Institutes & $\begin{array}{l}\text { Total } \\
\text { number of } \\
\text { questionnaire } \\
\text { administered }\end{array}$ & $\begin{array}{l}\text { Total number of } \\
\text { questionnaire } \\
\text { collected }\end{array}$ & Percentage \\
\hline $\begin{array}{l}\text { Forestry Research Institute of Nigeria } \\
\text { (FRIN) }\end{array}$ & 200 & 199 & 49.6 \\
\hline $\begin{array}{l}\text { Institute of Agricultural Research and } \\
\text { Training (IART) }\end{array}$ & 63 & 51 & 12.7 \\
\hline $\begin{array}{l}\text { Cocoa Research Institute of Nigeria } \\
\text { (CRIN) }\end{array}$ & 75 & 64 & 16.0 \\
\hline $\begin{array}{l}\text { National Horticultural Research } \\
\text { Institute (NIHORT) }\end{array}$ & 102 & 62 & 20.4 \\
\hline No Response & & 5 & 1.2 \\
\hline Total & $\mathbf{4 4 0}$ & $\mathbf{4 0 1}$ & $\mathbf{1 0 0 . 0}$ \\
\hline
\end{tabular}

Table 1 shows the administration of questionnaires to the selected four (4) research institutes and the total number of questionnaire gathered together from the field. In a nut shell, four hundred and forty (440) questionnaires were structurally designed and administered while only four hundred and one (401) questionnaires were correctly filled and collected for the analysis.

Table 2: Age Distribution of Respondents

\begin{tabular}{|l|r|r|}
\hline Variables & Frequency & Percentage \\
\hline $21-30$ & 130 & 32.4 \\
\hline $31-40$ & 192 & 47.9 \\
\hline $41-50$ & 29 & 7.2 \\
\hline $51-60$ & 19 & 4.7 \\
\hline NO & 31 & 7.7 \\
RESPONSE & & \\
\hline Total & $\mathbf{4 0 1}$ & $\mathbf{1 0 0 . 0}$ \\
\hline
\end{tabular}

Table 2 reveals that majority of the respondents were $192(47.9 \%)$ are within the age range of $31-40$ years old. and 130 (32.4\%) were of the age range of 21-30 years old. 
Table 3: Gender distribution of respondents

\begin{tabular}{|l|r|r|}
\hline Gender & Frequency & Percentage \\
\hline MALE & 280 & 69.8 \\
\hline FEMALE & 81 & 20.2 \\
\hline NO & 40 & 10.0 \\
RESPONSE & & \\
\hline Total & $\mathbf{4 0 1}$ & $\mathbf{1 0 0 . 0}$ \\
\hline
\end{tabular}

Table 3 reveals that majority of the respondents were male $280(69.8 \%)$ and their female counterpart were $81(20.2 \%)$. While $40(10.0 \%)$ of the respondents did not respond.

Table 4 Distribution of respondents according to rank/status

\begin{tabular}{|l|r|r|}
\hline \multicolumn{1}{|c|}{ Rank/Status } & Frequency & \multicolumn{1}{c|}{ Percentage } \\
\hline Research Officer I & 88 & 21.9 \\
\hline Research Officer II & 81 & 20.2 \\
\hline Senior Research & 35 & 8.7 \\
Officer & & \\
\hline $\begin{array}{l}\text { Assist Agric. } \\
\text { Superintendent }\end{array}$ & 38 & 9.5 \\
\hline Agric Superintendent & 54 & 13.5 \\
\hline $\begin{array}{l}\text { Senior Agric. } \\
\text { Superintendent }\end{array}$ & 64 & 16.0 \\
\hline No Response & 41 & 10.2 \\
\hline Total & $\mathbf{4 0 1}$ & $\mathbf{1 0 0 . 0}$ \\
\hline
\end{tabular}

Table 4 indicated that Research Officer I rank/status has the highest frequency of 88 (21.9\%), Research Officer II 81 (20.2\%), Senior Agric Superintendent 64 (16.0\%), Agric Superintendent 54 (13.5\%), while no response rank/status is 41 (10.2\%), Assist. Agric Superintendent38 (9.5\%) and Senior Research Officer have the least frequency of 35 (8.7\%). 
Table 5: Methods of knowledge sharing among researchers in research institutes

\begin{tabular}{|c|c|c|c|c|c|c|c|c|c|c|}
\hline \multirow[t]{2}{*}{ Methods } & \multicolumn{2}{|l|}{ SD } & \multicolumn{2}{|l|}{ D } & \multicolumn{2}{|l|}{$\mathbf{A}$} & \multicolumn{2}{|l|}{ SA } & \multirow[t]{2}{*}{ MEAN } & \multirow[t]{2}{*}{ Std. D } \\
\hline & $\mathbf{F}$ & $\%$ & $\mathbf{F}$ & $\%$ & $\mathbf{F}$ & $\%$ & $\mathbf{F}$ & $\%$ & & \\
\hline $\begin{array}{l}\text { Through face to } \\
\text { face. }\end{array}$ & 17 & 4.2 & 73 & 18.2 & 81 & 20.2 & 152 & 37.9 & 20.76 & 38.508 \\
\hline $\begin{array}{l}\text { By attending } \\
\text { seminars. }\end{array}$ & 28 & 7.0 & 75 & 18.7 & 54 & 13.5 & 244 & 60.8 & 1.72 & .999 \\
\hline Through trainings. & 19 & 4.7 & 99 & 24.7 & 40 & 10.0 & 220 & 54.9 & 7.36 & 22.655 \\
\hline $\begin{array}{l}\text { Through } \\
\text { workshops. }\end{array}$ & 50 & 12.5 & 49 & 12.2 & 99 & 22.7 & 144 & 35.9 & 18.22 & 36.239 \\
\hline $\begin{array}{l}\text { Through } \\
\text { conferences. }\end{array}$ & 86 & 21.4 & 53 & 13.0 & $\begin{array}{l}10 \\
3\end{array}$ & 25.7 & 121 & 30.2 & 11.82 & 28.673 \\
\hline $\begin{array}{l}\text { Through mobile } \\
\text { phones. }\end{array}$ & 161 & 40.1 & 208 & 51.9 & 1 & 2 & 1 & 2 & 10.58 & 25.181 \\
\hline $\begin{array}{ll}\text { Through } & \text { social } \\
\text { medias. } & \\
\end{array}$ & 30 & 7.5 & 46 & 11.5 & 74 & 18.5 & 239 & 59.5 & 14.06 & 30.619 \\
\hline Through e-mails. & 46 & 11.5 & 56 & 14.0 & 73 & 18.5 & 198 & 49.4 & 9.49 & 24.571 \\
\hline $\begin{array}{ll}\text { Through } & \text { notice } \\
\text { boards. } & \\
\end{array}$ & - & - & 22 & 5.5 & $\begin{array}{l}12 \\
5\end{array}$ & 31.2 & 212 & 52.9 & 13.31 & 29.350 \\
\hline $\begin{array}{l}\text { Through journals } \\
\text { publications. }\end{array}$ & 53 & 13.2 & 105 & 26.2 & $\begin{array}{l}10 \\
8\end{array}$ & 26.9 & 121 & 30.2 & 6.09 & 17.721 \\
\hline $\begin{array}{l}\text { Through online } \\
\text { search engines. }\end{array}$ & 1 & 2 & 1 & 2 & $\begin{array}{l}10 \\
7\end{array}$ & 26.7 & 293 & 73.1 & 1.27 & .463 \\
\hline $\begin{array}{l}\text { Through the use } \\
\text { of library services. }\end{array}$ & 46 & 11.5 & 59 & 14.7 & 87 & 21.7 & 163 & 40.6 & 13.53 & 30.619 \\
\hline $\begin{array}{l}\text { Through } \\
\text { electronics } \\
\text { databases. }\end{array}$ & 52 & 13.0 & 65 & 16.2 & 89 & 22.2 & 145 & 36.2 & 23.85 & 40.198 \\
\hline
\end{tabular}

KEY: SA= Strongly Agree; A=Agree; $\mathrm{D}=$ Disagree; $\mathrm{SD}=$ Strongly Disagree.

Table 5 shows the rating of the items on methods of knowledge sharing among researchers in research institutes. It revealed that through electronics databases (Mean $=23.85$ ). ranked highest in the mean score rating and was followed by face to face (Mean $=20.76$ ), workshops (Mean $=18.22$ ), social medias (Mean $=14.06)$, use of library services (Mean $=13.53$ ), notice boards $($ Mean $=13.31)$, conferences $($ Mean $=11.82)$, mobile phones $($ Mean $=10.58)$, e-mails 
(Mean =9.49), trainings (Mean =7.36), journals publications (Mean =6.09), attending seminars (Mean =1.72) and lastly followed by online search engines (Mean =1.27).

Table 6: Demographic factors of the researchers

\begin{tabular}{|l|l|l|l|l|l|l|l|l|l|l|}
\hline Statement & \multicolumn{4}{l}{ SD } & D & \multicolumn{1}{l|}{ A } & \multicolumn{1}{l|}{ SA } & MEAN & Std. D \\
\hline & F & \% & F & \% & F & \% & F & \% & & \\
\hline Age. & 99 & 24.7 & 94 & 23.4 & 103 & 25.7 & 105 & 26.2 & 2.46 & 1.111 \\
\hline Sex. & 94 & 23.4 & 94 & 23.4 & 99 & 24.7 & 99 & 24.7 & 6.08 & 18.372 \\
\hline Marital status. & 80 & 20.0 & $\mathbf{7 9}$ & 19.7 & 95 & 23.7 & 81 & 20.2 & 18.36 & 35.852 \\
\hline Religion. & 158 & 39.4 & 94 & 23.4 & 68 & 17.0 & 65 & 16.2 & 5.97 & 19.020 \\
\hline $\begin{array}{l}\text { Educational } \\
\text { Level }\end{array}$ & 85 & 21.2 & 74 & 18.5 & 112 & 37.9 & 130 & 32.4 & 2.28 & 1.131 \\
\hline $\begin{array}{l}\text { Cultural } \\
\text { background }\end{array}$ & 21 & 5.2 & 72 & 18.0 & 80 & 20.0 & 150 & 37.4 & 20.78 & 38.497 \\
\hline Language & 240 & 59.9 & 74 & 18.5 & 57 & 14.2 & 30 & 7.5 & 1.74 & 1.007 \\
\hline Family income & 24 & 6.0 & 102 & 25.4 & 41 & 10.2 & 211 & 52.6 & 7.41 & 22.642 \\
\hline
\end{tabular}

KEY: SA= Strongly Agree; A=Agree; D=Disagree; SD=Strongly Disagree.

Table 6 shows the rating of the items on the demographic factors of the researchers. It revealed that cultural background (Mean =20.78) ranked highest in the mean score rating and was followed by marital status (Mean =18.36), Family income (Mean =7.41), Sex (Mean =6.08), Religion (Mean =5.97), Age (Mean =2.46), Educational level (Mean =2.28), and lastly followed by Language (Mean =1.74).

Table 7: Challenges to knowledge sharing.

\begin{tabular}{|c|c|c|c|c|c|c|c|c|c|c|}
\hline \multirow[t]{2}{*}{ Statement } & \multicolumn{2}{|l|}{ SD } & \multicolumn{2}{|l|}{$\mathbf{D}$} & \multicolumn{2}{|l|}{$\mathbf{A}$} & \multicolumn{2}{|l|}{$\mathbf{S A}$} & \multirow[t]{2}{*}{ Mean } & \multirow{2}{*}{$\begin{array}{l}\text { Std. } \\
\text { D }\end{array}$} \\
\hline & NO & $\%$ & NO & $\%$ & NO & $\%$ & $\mathrm{~F}$ & $\%$ & & \\
\hline Lack of training. & 31 & 7.7 & 48 & 12.0 & 110 & 27.4 & 118 & $\begin{array}{l}29 . \\
4\end{array}$ & 24.87 & $\begin{array}{l}41.07 \\
9\end{array}$ \\
\hline $\begin{array}{l}\text { Poor knowledge of social } \\
\text { media use. }\end{array}$ & 121 & 30.2 & 97 & 24.2 & 23 & 5.7 & 93 & $\begin{array}{l}23 . \\
2\end{array}$ & 18.82 & $\begin{array}{l}35.97 \\
3\end{array}$ \\
\hline $\begin{array}{l}\text { Lack of institutional } \\
\text { policy to support } \\
\text { knowledge sharing. }\end{array}$ & 87 & 21.7 & 142 & 35.4 & 65 & 16.2 & 46 & $\begin{array}{l}11 . \\
5\end{array}$ & 17.43 & $\begin{array}{l}34.60 \\
6\end{array}$ \\
\hline
\end{tabular}




\begin{tabular}{|l|l|l|l|l|l|l|l|l|l|l|}
\hline $\begin{array}{l}\text { Believe that one's } \\
\text { knowledge would be } \\
\text { taken away if shared with } \\
\text { others. }\end{array}$ & 28 & 7.0 & 43 & 10.7 & 57 & 14.2 & 232 & $\begin{array}{l}57 . \\
9\end{array}$ & 11.59 & $\begin{array}{l}29.55 \\
1\end{array}$ \\
\hline $\begin{array}{l}\text { Educational level of } \\
\text { researchers would } \\
\text { determine knowledge } \\
\text { sharing. }\end{array}$ & 59 & 14.7 & 33 & 8.2 & 131 & 32.7 & 178 & $\begin{array}{l}44 . \\
4\end{array}$ & 1.93 & 1.055 \\
\hline $\begin{array}{l}\text { The motivation to share } \\
\text { knowledge with their } \\
\text { colleagues. }\end{array}$ & 102 & 25.4 & 128 & 31.9 & 44 & 11.0 & 112 & $\begin{array}{l}27 . \\
9\end{array}$ & 5.71 & 17.18 \\
\hline $\begin{array}{l}\text { Poor internet } \\
\text { connectivity to access } \\
\text { inter-based resources } \\
\text { would affect researcher } \\
\text { to share knowledge with } \\
\text { his/her other colleagues. }\end{array}$ & 88 & 21.9 & 59 & 14.7 & 108 & 26.9 & 146 & 36. & 2.22 & 1.159 \\
\hline
\end{tabular}

KEY: $\mathrm{SA}=$ Strongly Agree; A=Agree; $\mathrm{D}=$ Disagree; $\mathrm{SD}=$ Strongly Disagree.

Table 7 shows the rating of the items on Challenge to knowledge sharing. It revealed that Lack of training (Mean $=24.87$ ) ranked highest in the mean score rating and was followed by Poor knowledge of social media use (Mean $=18.82$ ), Lack of institutional policy to support knowledge sharing (Mean =17.43), Believe that one's knowledge would be overshadowed/taken away if share with others (Mean =11.59), The motivation to share knowledge with their colleagues (Mean $=5.71)$, Poor internet connectivity to access inter-based resources would affect researcher to share knowledge with his/her other colleagues (Mean $=2.22$ ) and lastly followed by Educational level of researchers would determine knowledge sharing (Mean =1.93).

Table 8: Influence of gender on knowledge sharing

\begin{tabular}{|l|l|l|l|l|l|l|}
\hline Variables & $\mathbf{N}$ & Mean & $\begin{array}{l}\text { Standard } \\
\text { Deviation }\end{array}$ & $\begin{array}{l}\text { Pearson } \\
\text { coefficient } \\
(\mathbf{r})\end{array}$ & Sig & Remark \\
\cline { 1 - 1 } $\begin{array}{l}\text { Knowledge } \\
\text { sharing }\end{array}$ & 401 & 152.0549 & 106.40102 & .091 & .070 & Sig \\
\cline { 1 - 4 } Gender & 401 & 10.98 & 29.339 & 1 & 1 & \\
\hline
\end{tabular}

Table 8 shows the correlation table of gender and knowledge sharing with values $(r=0.1$; 
$\mathrm{p}<0.05$ ), Since $\mathrm{P}$ is less than 0.05 ; it shows that gender will significantly influence knowledge sharing.

Table 9: Influence of rank/status on knowledge sharing

\begin{tabular}{|c|c|c|c|c|c|c|}
\hline Variables & $\mathbf{N}$ & Mean & $\begin{array}{l}\text { Standard } \\
\text { Deviation }\end{array}$ & $\begin{array}{l}\text { Pearson } \\
\text { coefficient } \\
\text { (r) }\end{array}$ & Sig. & Remark \\
\hline $\begin{array}{l}\text { Knowledge } \\
\text { sharing }\end{array}$ & 401 & 152.0549 & 106.40102 & $-.121 *$ & \multirow[t]{2}{*}{.016} & \multirow[t]{2}{*}{ Sig } \\
\hline Rank/status & 401 & 13.02 & 29.107 & 1 & & \\
\hline
\end{tabular}

*correlation is significant at the 0.05 level (2-tailed).

Table 9 shows the correlation table of rank/status and knowledge sharing with values ( $r=0.1$; $\mathrm{p}<0.05$, since $\mathrm{P}$ is less than 0.05 it shows that rank/status will significantly influence knowledge sharing.

Table 10: Influence of demographic factors on knowledge sharing

\begin{tabular}{|l|l|l|l|l|l|l|}
\hline Variables & N & Mean & $\begin{array}{l}\text { Standar } \\
\mathbf{d} \\
\text { Deviatio } \\
\mathbf{n}\end{array}$ & $\begin{array}{l}\text { Pearson } \\
\text { coefficient } \\
(\mathbf{r})\end{array}$ & $\begin{array}{l}\text { Sig } \\
(\mathbf{t})\end{array}$ & $\begin{array}{l}\text { Remar } \\
\mathbf{k}\end{array}$ \\
\hline Knowledge sharing & 401 & $\begin{array}{l}152.05 \\
49\end{array}$ & $\begin{array}{l}106.4010 \\
2\end{array}$ & 1 & & \\
\hline Age & 401 & 2.46 & 1.111 & .038 & .449 & $\begin{array}{l}\text { Not } \\
\text { Sig. }\end{array}$ \\
\hline Sex & 401 & 6.08 & 18.372 & $-.231^{* *}$ & .000 & Sig. \\
\hline Marital Status & 401 & 18.36 & 35.852 & -.216 & .000 & Sig. \\
\hline Religion & 401 & 5.97 & 19.020 & $.225^{* *}$ & .000 & Sig. \\
\hline Educational level & 401 & 2.28 & 1.131 & .005 & .926 & $\begin{array}{l}\text { Not } \\
\text { Sig. }\end{array}$ \\
\hline $\begin{array}{l}\text { Cultural } \\
\text { background }\end{array}$ & 401 & 20.78 & 38.497 & $.417^{* *}$ & .000 & Sig. \\
\hline Language & 401 & 1.74 & 1.007 & .090 & .072 & $\begin{array}{l}\text { Not } \\
\text { Sig. }\end{array}$ \\
\hline Family income & 401 & 7.41 & 22.642 & $.241^{* *}$ & .000 & Sig. \\
\hline
\end{tabular}

$* *$ correlation is significant at the 0.05 level (2=tailed).

*correlation is significant at the 0.05 level (2-tailed)

Table 10 shows that cultural background has the highest significant demographic factors 
influence on knowledge sharing ( $\left.\mathrm{r}=0.417^{* *} ; \mathrm{t}=0.000 ; \mathrm{p}>0.05\right)$; followed by marital status $(\mathrm{r}=0.216 ; \mathrm{t}=0.000 ; \mathrm{p}>0.05)$, followed by religion $\left(\mathrm{r}=0.255^{* *} ; \mathrm{t}=0.000 ; \mathrm{p}<0.05\right)$, followed by sex $\left(\mathrm{r}=0.231^{* *} ; \mathrm{t}=0.000 ; \mathrm{p}<0.05\right)$, followed by language $(\mathrm{r}=0.090 ; \mathrm{t}=0.072 ; \mathrm{p}>0.05)$; followed by cultural background $(\mathrm{r}=0.072 ; \mathrm{t}=0.147 ; \mathrm{p}>0.05)$, age $(\mathrm{r}=0.38 ; \mathrm{t}=0.449 ; \mathrm{p}>0.05)$ and educational level $(\mathrm{r}=0.005 ; \mathrm{t}=0.926 ; \mathrm{p}>0.05)$.

The finding reveals that male respondents are the majority in the study. The study reveals that the major methods of knowledge sharing among the respondents are through seminars, training, workshop, conferences, social media and online search engines. Ma and Chan (2014) highlighted the role of social media in knowledge sharing. Their finding shows that elements of social media include altruism, perceived online attachment motivation, and perceived online relationship commitment influences knowledge sharing. The findings reveal that the researcher's demographic factors correlated significantly in this order with: age, gender, marital status, educational level, cultural background, language and family income. This is line with the study of Grubić-Nešić, Matić and Mitrović (2014) that shows that gender, level of education, organizational tenure and advance at work have significant impact on knowledge sharing. The study is against the Ismail and Yusof (2009) and Mogotsi, Boon and Fletcher (2011) in their irrespective findings, that demographic variables are not significant predictors of knowledge sharing behaviour. Finally, the challenges encounter by the respondents in knowledge sharing are lack of training, overshadow of one's knowledge, educational level of the researchers and poor Internet Connectivity. Top (2012) found empirically that the highest risk in knowledge sharing in house, is the lack of technical infrastructure and information system. Thus, technical infrastructure and IT provide employees with the ability to share, obtain feedback, and create ideas (Connelly \& Kelloway, 2003). Szulanski (1996) specified some impediments that hamper knowledge sharing like, dependability of source, motivation to share their knowledge, and ability to learn. According to these impediments, Sai and Sheng (2006) stated that individuals are unwilling to share their knowledge except there are obvious benefits for them. It is important to explicate individual knowledge sharing behaviour, to break down these impediments. In general terms, research on knowledge sharing barriers tends to fall into several basic areas (a) cultural background (e.g. age, ethnicity, educational level) affects knowledge sharing (Ardichvili et al 2006 and Riege, 2005); (b) organizational culture affects knowledge sharing (Connelly and Kelloway, 2003; Bock and Kim, 2002); and (c) IT support affects willingness to share knowledge (Connelly and Kelloway, 2003).

\section{Conclusion and recommendations}

Researchers need to understand how to transfer and work with knowledge, share it and create conditions on how to use it. The understanding of knowledge will become a source of intellectual capital through its expression in goods and services. Knowledge sharing is "the process of 
transferring knowledge from a person to another in an organization. However, it has been observed that researchers in the research institutes in Nigeria do not freely share knowledge with one another. In addition, institutional factors (managerial style, organisational culture, organisational structure, facilities, resources and policy) of most research institutes in Nigeria seem to be rigid and usually take a long process to change. The following recommendations were made based on the findings of the study:

a. Research institutes in Nigeria should give all necessary encouragement to the researchers to improve their knowledge sharing behaviour and also acknowledge the personnel whose knowledge has led to an innovative process and growth of the organisation.

b. Research institutes should also improve on their managerial style so that researchers will feel free to share knowledge with one another.

c. The research institutes should do everything possible to provide ICT facilities and more especially, effective Internet connection to facilitate knowledge sharing process.

d. Adequate funds should be allocated to the research institutes by the government so that researchers will undergo training and re-training so that they will be loaded with innovative ideas to share.

\section{References}

Ardichvili, A., Maurer, M., Li, W., Wentling, T., \& Stuedemann, R. (2006) Cultural influences on knowledge sharing through online communities of practice. Journal of knowledge management, 10 (1): 94-107

Ardichvili, A., Page, V. \& Wentling, T. (2003) Motivation and barriers to participation in virtual knowledge-sharing communities of practice. Journal of Knowledge Management, 7(1): 64-77

Bock, G., Zmud, R. W, Kim, Y. and Lee, J. (2005) Behavioural intention formation in knowledge sharing: examining the roles of extrinsic motivators, Social-Psychological forces and organizational climate. 29 (1): 87-111. Retrieved 30 ${ }^{\text {th }}$ April, 2015 from http://www.jstor.org/page/info/about/policies/fems/jsp

Bock, G. W., \& Kim, Y. G. (2002). Breaking the myths of rewards: An exploratory study of attitudes about knowledge sharing. Information Resources Management Journal, (15):

14- 21.

Chou, H. W., Lin, Y. H., Lu, H. S., Chang, H. H., \& Chou, S. B. (2014). Knowledge sharing and ERP system usage in post-implementation stage. Computers in Human Behavior, (33): $16-22$. 
Connelly, C. E. and Kelloway, E. K. (2003) Predictors of employees' perceptions of knowledge sharing cultures. Leadership \& Organization Development Journal, 24(5/6): 294-301.

Connelly, C. \& Kelloway, K. (2000). Predictors of knowledge sharing in organizations, Thesis for Queen's School of Business, Queen's University, Kingston, ON.

Cummings, J. N. (2004) Work groups, structural diversity, and knowledge sharing in a global organization. Management Science, 50(3): 352-364.

Gibbert, M. and Krause, H. (2002) Practice exchange in a best practice marketplace,' in Davenport, T.H and Probst, G.J.B. (eds.) (2002) Knowledge management case book: Siemen Best Practices. Erlangen, Germany: Publicis Corporate Publishing,

Gold, A., Malhotra, A. and Segars, A. (2001) Knowledge management: An organizational capabilities perspective," Journal of Management Information Systems, (18):185-214.

Grant, R. M. (1996) Toward a knowledge-based theory of the firm. Strategic Management Journal, (17): 109-122.

Grubić-Nešić, L., Matić, D. and Mitrović, S. (2014) The influence of demographic and organizational factors on knowledge sharing among employees in organizations. Retrieved on $4^{\text {th }}$ April, 2017 from DOI: 10.17559/TV-20141216213746

Hawamdeh, S. (2003) Knowledge Management Cultivating Knowledge Professionals, Oxford: Chandos Publishing.

Ismail, M.B. and Yusof, Z.M. (2009) Demographic factors and knowledge sharing quality among Malaysian Government Officers. Communications of the IBIMA, (9): 1-8

Jackson, S. E., Chuang, C. H., Harden, E. E., and Jiang, Y. (2006) Toward developing human resource management systems for knowledge-intensive teamwork. Research in personnel and human resources management, (25):27-70

Kathiravelu, S. R., Mansor, N. N. A., Ramayah, T., \& Idris, N. (2014). Why organisational culture drives knowledge sharing?. Procedia-Social and Behavioral Sciences, (129): 119126

Lee, H. S., \& Hong, S. (2014) Factors affecting hospital employees' knowledge sharing intention and behaviour, and innovation behaviour. Osong Public Health and Research Perspectives.

Liebowitz, J. (2001) Knowledge management and its link to artificial intelligence. Expert Systems with Applications, (20): 1-6.

Lin, H. (2007). Effects of extrinsic and intrinsic motivation on employee knowledge sharing intentions. Journal of Information Science, (33): 135-149.

Ma, W. W., and Chan, A. (2014) Knowledge sharing and social media: Altruism, perceived online attachment motivation, and perceived online relationship commitment. Computers in Human Behavior, (39): 51-58.

Mogotsi, I. C., Boon, J.A. and Fletcher, L. (2011) Knowledge sharing behaviour and demographic variables amongst secondary school teachers in and around Gaborone, Botswana. SA Journal of Information Management; 13(1):1- 6. Retrieved on $3^{\text {rd }}$ March, 
2017, from doi: 10.4102/sajim.v13i1.420

Mohamed, Z. A., Ann, H. J., \& Yee, W. P. (2014) Strategic management. Oxford University Press.

Mueller, J. (2012). Knowledge sharing between project teams and its cultural antecedents. Journal of Knowledge Management, 16(3): 435-447.

Politis, J. D. (2003) The connection between trust and knowledge management: what are its implications for team performance. Journal of Knowledge Management, 7(5): 55-66

Pulakos, E. D., Dorsey, D. W., \& Borman, W. C. (2003). Hiring for knowledge-based competition. In : S. E. Jackson, M. A. Hitt \& A.S. Denisi (Eds.), Managing knowledge for sustained competitive advantage: Designing strategies for effective human resource management. San Francisco: Jossey-Bass, pp. 155-176

Riege, A. (2005), “Three-dozen knowledge sharing barriers managers must consider”, Journal of Knowledge Management, 9 (3): 8-35.

Sai, H.K., \&Sheng, G. (2006). Attitude toward knowledge sharing behavior. The Journal of Computer Information System, 46(2): 45-51.

Shi-Jer Lou, Yun-Shiue Yang, Ru-Chu Shih \& Kuo-Hung Tseng (2007): A Study on the knowledge sharing behaviour of Information Management Instructors at Technological Universities in Taiwan, World Transactions on Engineering and Technical Education, 6(1):143-148.

Spender, J. C. (1996) "Making knowledge the basis of a dynamic theory of the Firm," Strategic Management Journal, (17): 45-62.

Steyn, G.M. (2004), "Harnessing the power of knowledge in higher education", Education, 124 (4): 615-17.

Swart, J. and Kinnie, N. (2003), "Sharing knowledge in knowledge-intensive firms", Human Resource Management Journal, 13 (2): 60-75.

Szulanski, G. (1996). "Exploring internal stickiness: Impediments to the transfer of best practice within the firm," Strategic Management Journal, 17 (Summer special issue): 27-43.

Top, S. (2012) Assessing the knowledge sharing in terms of risk level in-house service sector assisted with system usage in post-implementation stage. Computers in Human Behaviour, (33): 16-22.

Van Acker, F., Vermeulen, M., Kreijns, K., Lutgerink, J., \& van Buuren, H. (2014). The role of knowledge sharing self-efficacy in sharing open educational resources. Computers in Human Behaviour, (39): 136-144.

VonKrogh G. (1998) Care in knowledge creation, California Management Review,.40 (3): 133153.

Wiig, K. (2004). People-focused knowledge management: How effective decision making leads to corporate success. Burlington: Elsevier Butterworth-Heinemann. 
Folashade Munirat Lawal and Chuks Daniel Oriogu are librarians with Afe Babalola University, Ado-Ekiti, Ekiti State. They can be contacted on princessshade02@gmail.com, and oriogucd@abuad.edu.ng respectively. Sussan Udoaku Ogbuiyi works with Babcock University Library, Illisan-Remeo, Ogun State, Nigeria. She can be reached at ogbuiyis@ babcock.edu.ng. 